\title{
Perceptions about the health condition of people with obesity
}

\author{
Percepções acerca da condição de saúde de pessoas com obesidade
}

Cátia Suely Palmeira ${ }^{1}$, Laíne Maria Monteiro Garrido², Maria de Lourdes Lima², Armênio Costa Guimarães², Ana Marice Teixeira Ladeia ${ }^{2}$

Objective: to understand the perceptions of people with obesity on this health condition. Methods: qualitative research conducted in an outpatient clinic for follow-up of people with obesity. 15 people diagnosed with obesity were interviewed. Data were collected by interviews and submitted to thematic content analysis. Results: three categories emerged: Giving meaning to obesity, Affecting everyday life and health and Facing obesity. In the first category, the majority of respondents gave negative meaning to their own obesity; in the second, they perceived it as a condition capable of causing damage to health and labor capacity; and in the third, it was referred as a condition that must be faced and treated. Conclusion: perceptions on obesity reflected, above all, negative feelings, accompanied by some degree of physical, mental and social suffering.

Descriptors: Obesity; Perception; Nursing.

Objetivo: compreender as percepções de pessoas com obesidade sobre esta condição de saúde. Métodos: pesquisa qualitativa realizada em ambulatório para acompanhamento de pessoas com obesidade. Foram entrevistadas 15 pessoas com diagnóstico de obesidade. Dados coletados por entrevistas e submetidos à Análise de Conteúdo Temática. Resultados: emergiram três categorias: Significando a obesidade, Afetando a vida cotidiana e a saúde e Enfrentando a obesidade. Na primeira categoria, a maioria dos entrevistados significou negativamente a própria obesidade; na segunda, perceberam-na como condição capaz de provocar dano à saúde e à capacidade laboral; e, na terceira, como condição que precisa ser enfrentada e tratada. Conclusão: as percepções da obesidade refletiram, sobretudo, sentimentos negativos, acompanhados de algum grau de sofrimento físico, psíquico e social.

Descritores: Obesidade; Percepção; Enfermagem.

\footnotetext{
${ }^{1}$ Escola de Enfermagem da Universidade Federal da Bahia. Salvador, BA, Brazil.

${ }^{2}$ Escola Bahiana de Medicina e Saúde Pública. Salvador, BA, Brazil. 


\section{Introduction}

Obesity has a complex and multifactorial etiology and is the result of interaction between genetic, environmental and personal factors. This is an increasingly frequent disease that has reached epidemic proportions throughout the world. It affects all ages and socioeconomic groups, burdening health services and representing one of the main problems of today's public health ${ }^{(1-2)}$. In the 27 Brazilian capitals, in 2014, the frequency of obesity in adults reached the percentage of $17.9 \%$, with no differences between genders and with tendency to increase with age. In Salvador, the percentage of obese people is $18.2 \%{ }^{(3)}$.

Obesity increases the primary risk of developing conditions such as hypertension, dyslipidemia, type 2 diabetes and diseases of musculoskeletal system. In the psychological sphere, changes in body image are often associated to reduced self-esteem ${ }^{(4)}$. Since obesity is a disease that changes body and mind, it can relate to various social aspects (employment difficulties, prejudice, exclusion and isolation), psychological problems (low self-esteem) and physical problems (difficulty in mobility and in performing daily activities ${ }^{(5)}$.

The excess weight control is not a simple and straightforward task and is a challenge to health professionals. There is no long-term effective approach that does not involve lifestyle changes, particularly with respect to nutrition and regular physical activity. These aspects of the problem make it necessary to use a multidisciplinary approach, as this enables that several factors involved in the genesis and maintenance of overweight are observed with different, but complementary, views and knowledge, which are necessary in the monitoring process ${ }^{(4)}$.

Living with obesity may require that the person has perception and understanding of the disease and its complications, as well as ways to face and overcome their disease process. The knowledge about the perception that a person has of their healthdisease process allows professionals to individualize care strategies.

In searching in the main national and international databases, it was found that although there are many studies on obesity, there were no studies investigating the perceptions and feelings of adults regarding this health condition, as well as the way that they face this disease. The studies that address this issue refer to patients undergoing bariatric surgery or to other chronic health conditions, and those who deal with the subjective aspects of obesity are mostly aimed at the perception of body image and conducted by psychologists. Thus, seeking understanding beyond the clinical features of the disease, by considering the perceptions of people about this health problem, can contribute to the effectiveness of new care practices and fill a gap in the literature. Given this context, this study aimed to understand the perceptions of people with obesity on this health condition.

\section{Methods}

This is a qualitative study conducted in an obesity reference service of a private higher education institution in the city of Salvador, Brazil. For the selection of participants, people who attended the health service were invited to a scheduled appointment.

The study enrolled 15 subjects, and as it is a qualitative study, there was not a fixed number of participants; researchers adopted the principle of data saturation, which is used to establish or close the final size of a sample in a qualitative study, by interrupting enrollment of new participants when the data start to show redundancy or repetition, in the investigator's assessment ${ }^{(6)}$. The criteria for composing the sample were being registered and monitored by the service, having a body mass index $\geq 30 \mathrm{~kg} / \mathrm{m}^{2}$ and being over 18 years old. People with severe mental illnesses previously diagnosed and could not participate in the interview were excluded.

Data collection took place between November 2012 and March 2013 during a single meeting in an 
individual service room, which provided greater privacy. The authors conducted an interview guided by a semi-structured tool developed by them. The interview included questions related to socio-demographic data (gender, age, marital status and education), clinical data (diagnosis of other comorbidities) and subjective questions on perception of obesity and ways of coping with this disease and its treatment. Each interview lasted about 30 minutes and were all recorded with permission of the participants, and later transcribed. The anonymity of respondents was maintained, being assigned to each participant the letter " $\mathrm{P}$ " and numbered from 1 to 15 .

After reading the transcribed data, these were analyzed based on content analysis. This technique consists in discovering the core meanings that compose communication, whose presence or frequency has meaning to the targeted analytical objective $^{(7)}$. The first stage consisted of exhaustive reading of the speeches, in order to set the record units, also called meaning units. Later, researchers sought to reflect more deeply on the content of each speech, aiming at understanding their essence, and then performed the separation and grouping of content by convergence, turning them into categories. The results, presented descriptively and accompanied by exemplification of significant record units for each category, were interpreted based on the literature.

The study complied with the formal requirements contained in the national and international regulatory standards for research involving human beings.

\section{Results}

From the analysis of the reports, the following categories emerged: Giving meaning to obesity, Affecting everyday life and health, Facing obesity.

\section{Giving meaning to obesity}

Most respondents attributed a negative mea- ning to their own obesity. Words such as fear, sadness, bad, horrible, uncomfortable and terrible appeared very frequently in the speeches and revealed some degree of suffering arising from excess weight. Excess weight for me is horrible, it affects me a lot. No fat person is happy, that is the truth (P10). Being overweight is sad, it is horrible, I do not accept it (P9). I am very scared of having more serious health problems in the future because of my weight (P13).

The reports of respondents evidenced several ways in which the disease was experienced, felt and understood. The reports also showed that excess weight was closely related to decreased self-esteem. Self-esteem is shaken up because of the jokes we hear for being overweight, it becomes very low (P3). Being overweight changes many things in my life, my self-esteem is shaken (P13).

Before the condition of being obese, a person felt stigmatized: Overweight becomes a point of reference "that chubby lady there." When I complain to someone that I am having trouble with losing weight, this person thinks it is just because of food and that there are no other health problems involved. So there is this stigma, that a person who is fat is lazy (P3).

For some people, living with obesity means isolation and exclusion, resulting, sometimes, in a defense mechanism against negative evaluations from others: It is hard to find clothes for fat people. I lock myself in my own world, even to avoid hearing certain jokes. I have no joy and do not have fun anymore, I do not get out much; going to the beach is impossible (P3). I do not feel like going out, I invent a lot of excuses when it is time to go out, I say that I have no clothes, that the clothes do not fit, but it is actually because of the weight that I do not want to leave (P5). I have gave up of going out several times, feeling ugly (P13).

It was noted that not all respondents had the same pattern of negative feelings, low self-esteem and discomfort related to the condition of being obese: Until now, being overweight does not change anything in my life. I do not see it as a disease. I try to take it lightly, so that I have more willpower. Excess weight did not influence at all in relation to selfesteem, because I have always tried to see this aspect in the best possible way (P15). I do not get very uncomfortable with my weight. I do not think I am "that big fat lady," I do not get troubled with my body that much (P6). This thing of keeping watching myself in the 
mirror and finding myself ugly, this was never my concern, I take it lightly and face as a learning (P7).

\section{Affecting everyday life and health}

In this category, there was emphasis on the perception of obesity affecting the development of daily activities. Overweight affects my readiness I am a journalist and have to walk a lot and travel a lot to do a lot of research. So because of excess weight, sometimes I cannot keep up with my coworkers' pace (P7). I feel tired more easily because I work in my house and at another lady's house, and now I am no longer being able to have the quickness I had before (P11).

Many related their current health status, the development of diseases and symptoms such as hypertension, diabetes, osteoarthritis, pain, dyspnoea and limited mobility with obesity: With regard to health, I feel pain all over the body, high blood pressure; I have already been hospitalized due to shortness of breath. It is horrible; it seems that weight affects the entire body (P10). Besides being heavy, I have diabetes, problem in my knees, in my back trouble, I am shortsighted, so for me it is bad to live like that. The column also bothers me a lot, so I am not feeling well. This all started only after I started to put on weight, the pain and the disease aroused, the tiredness, everything (P4). My legs really hurt, they keep locking when I walk (E6). Excess weight, for me, means less health, being less healthy. Hypertension, I think I got it because of excess weight. Most of the time, I cannot walk much, because I get tired, I fell very unwell, unwilling to do anything (P12).

Other problems perceived by the participants referred to the cognitive dimension and psychological disorder: I believe that obesity also influences my thinking, because I feel very drowsy (P7). With this weight, I got depressed (P8).

\section{Facing obesity}

This category addressed how participants related the perception of being obese to the strategies used to cope with the disease and respond to the demands imposed by therapy. In this context, obesity appeared as a challenge to be faced and overcome, particularly as referred to control eating habits. I have to control myself not to eat too much, or not drink soda, I have control myself, I cannot eat anything nor at any time (P13). I cannot let obesity take control over me (P14).

The attention to diet has emerged as the main way to address and overcome the overweight, especially when it referred to the choice of food, the amount and time: I am changing the diet and establishing my limit of food and the right times. So, I eat less and at appropriate times (P1). To lose weight I follow the food table that says what I can eat and what I have to eat every three hours (P2). To lose weight, I am only cutting down on my eating. For me, cutting down on my eating means not eating things I know I cannot eat. If I know I cannot eat flour, so I do not eat flour (P4). To lose weight, I am changing the diet and eating at the right times, and I will start hiking. I follow the diet that the nutritionist prescribed, I follow everything right (P1).

The strategy used to deal with the control of obesity can vary from person to person and, for some, it may cause that they avoid facing a conflict situation, as evidenced by one of the interviewees when she reported that she avoided social events not to break the diet. I also avoid going out to have fun in order to avoid eating something that makes me even more fat (P3).

Another reported way of combating obesity was physical activity: Today, to lose weight, I practice various types of physical activities. I play soccer three times a week; I run three times a week and practice tennis once a week. Every day I do exercises and each activity lasts about 2 hours (P15). I exercise every day for 1 hour 30 minutes to 2 hours. I do bodybuilding and I also walk in the treadmill and ride a bike three times a week (P9).

Those who did not exercise sought to justify it by stating excuses, thus revealing that they knew that this is an important strategy for reducing weight: As I work doing research, I end up walking a lot. Sometimes I walk for three hours straight in the afternoon. But going for a walk, leaving early in the morning determined to walk, there has been about five years since I did that (P7).

The demand for health professionals support was revealed as a way to overcome barriers in fighting the disease and its treatment and evidenced the perception on the performance of a multidisciplinary 
team in their monitoring: All I did was following medical advice. Following medical advice, I live normally, I work, I do everything. I went to psychologists and they advised me to see obesity naturally, because the head commands it all and if I get troubled, it will not work (P7). Today, I am monitored by the endocrinologist and the nursing staff (P6). A psychological work was needed to help me losing weight and quit eating what I was used to (P10). I tried to get less involved with family problems, trying to keep my life more balanced, to also help in weight loss (P3).

Despite the search for treatments without guidance from a health professional have been mentioned by only one of the respondents, this deserves highlight, since the use of "slimming formulas" with no prescription, although bringing high risk for health, was not unusual. Once I took a medicine to lose weight on my own, but I left it on my own, too (P8).

\section{Discussion}

Although this study had been performed in single reference service, representing the perceptions of a particular group, and had not contemplated all the complexity that involves the perception of obesity in the individual's perspective, it can contribute to new thinking about individualized interventions focusing not only on clinical aspects, but also on the subjectivity of the subject in order to assist them in improving selfesteem, coping on the disease and treatment and with well-being.

The analysis of the results suggests that obesity was perceived as a "problem" related to difficulties in the various dimensions of people's lives, such as physical, psychological and social. Thus, negative feelings, such as sadness, low self-esteem and rejection, may be generators of great psychological suffering, which can make even more difficult to deal with the problem and the therapy to be followed.

The perception of the obese patients appears to be strongly related to the vision that society has of them, which is usually negative in relation to appearance ${ }^{(8)}$. Obesity, as a stigmatizing condition, reinforces feelings of depreciation, devaluation and shame and may lead the individual to experience humiliating situations, isolation and social withdrawal ${ }^{(9-10)}$. The value that one gives to oneself, allowing them to have confidence, is shaped during life as a product of interactions between the individual, the family and society, and can interfere with physical and mental health of individuals, with repercussions on social and affective life, and on self-esteem, well-being and quality of life ${ }^{(11-12)}$.

Sociocultural patterns have linked the stereotype of the association between lean body and positive attributes such as beauty and success, motivating overweight people to develop suffering and psychological disorders consciously or unconsciously ${ }^{(5)}$. As regards the social aspects, the isolation reported by obese patients is associated with feelings of shame, body dissatisfaction and the nonacceptance of their image ${ }^{(9,12)}$.

Due to stigma and social discrimination that accompany obesity, the obese person is impaired in various aspects of life and is often blamed for their problem in different social environments, at home, in the workplace and in health services ${ }^{(13)}$. Labeling overweight people in a disparaging manner and blaming them for their condition, as noted in the speeches, evidences that the health team approach should include these aspects that are so present in the life of obese people and that can cause so much damage to their lives. The approach of these people by the health team should not be a process of prescribing recipes for weight control, but it should mainly consider subjective aspects of each of them, because what is at stake is not only restricted to change in food consumption and physical activity, but the influence on the meanings attached to eating, to the body and to the living ${ }^{(14)}$.

The analysis of the speeches also allowed identifying the perception of the impact of obesity as a harmful condition to health. The impairment of the locomotor system, especially in the joints and damage to the cardiovascular system, whether the emergence or the worsening of diseases such as hypertension 
and diabetes, as perceived by obese people were also reported in other studies ${ }^{(15-16)}$. Following this same path, it is emphasized the recognition of clinical manifestations associated with excess weight, such as pain, fatigue, malaise and indisposition, which impacts in activities of daily life and work ${ }^{(9)}$. The person with obesity may face working conditions that are not suitable for their condition, which limits, isolates and weakens them in many ways. They may also face decreased agility and mobility required to perform certain professional activities, which may cause stress and feelings of incapacitation and lower value ${ }^{(17)}$.

An important point to note is how the research participants reported coping with the disease and the treatment regimen. Terms used by them, as "fight" and "control" are linked to concepts of self-control and perseverance, which can oppose to biological trends and environmental pressures. Not overcoming certain phases of this daily struggle or being unable to control themselves can mean a personal failure and be associated with a feeling of helplessness. This aspect becomes more significant, since the results of a nutritional education for weight loss are more promising initially and get reduced over time, which may discourage the person to continue the treatment ${ }^{(14)}$.

The two weight reduction pillars are nutrition and physical activity. These were perceived as essential in the treatment of weight reduction. However, changing eating habits was the essential aspect, not only for reduction but also for weight maintenance ${ }^{(4)}$. It is important to note that food behavior changes will not be for little time nor will provide early results. This requires that the professional help the patient to understand that new habits need to be rebuilt and assimilated into the daily life in the long term ${ }^{(18)}$.

Considering the benefits of physical activity in the control of obesity and knowing that its practice can be reduced with the emergence of common musculoskeletal clinical manifestations in obesity and with aging ${ }^{(19)}$, health professionals need to be aware of the specificities of each person in order to help them to face and overcome difficulties inherent in their disease process.

Given that obesity is characterized by a multidimensional nature and that its approach demands monitoring by a multidisciplinary team ${ }^{(4,15)}$, it is noteworthy that participants had recognized the importance of the work of different professionals. Treatment should be understood as a process that requires personal effort and that despite the adherence capacity belongs to the individual, specialized and committed professionals can help them through proper guidance ${ }^{(20)}$.

As the perception of the disease is individual, the issue of obesity cannot be decontextualized, because it derives from on a combination of different ways of life of individuals. It is important to stress that strategies should be designed from the reality, uniqueness and difficulties of individuals, considering the application of self-care with the body and the rescue of their self-esteem as an important target of therapeutic approach.

In attending people with obesity, every health professional should develop new alternatives to consider all of these issues, not including rigid prescriptions and demands related to weight loss. To understand and deal with the subjective issues of the obese person, it is essential to recognize them as a subject that has different emotions and feelings.

\section{Conclusion}

The participants perceived the obese condition in different ways, but they often covered meanings and situations that extrapolated body weight. Obesity was perceived not only as a condition that causes damage to physical health, to social and working life, but also as a condition that generates suffering due to dissatisfaction with body image, loss of self-esteem and problems of discrimination, social exclusion and isolation.

With regard to the relation between obesity and health status, most respondents perceived it 
as a cause for other diseases or as aggravating the pre-existing health problems, and sought to face the disease through eating habits change and practice of physical activity, also understood that these changes are not easy and have to be maintained in the long term. Another outstanding way to tackle the disease was the participation of several professionals in their monitoring.

\section{Acknowledgements}

To the Fundacao de Amparo a Pesquisa do Estado da Bahia by the financial support for this work through Scientific Initiation scholarship.

\section{Collaborations}

Palmeira CS and Garrido LMM contributed to the project design, organization and interpretation of data, article writing and final approval of the version to be published. Lima ML, Guimarães AC and Ladeia AMT contributed to the critical review of the intellectual content of the article.

\section{References}

1. Word Health Organization. Controlling the global obesity epidemic [Internet]. 2015 [cited 2016 Jul 8]. Available from: www.who.int/nutrition/ topics/obesity/en/

2. Stevens GA, Singh GM, Lu Y, Danaei G, Lin JK, Finucane MM, et al. global burden of metabolic risk factors of chronic diseases collaborating group (Body Mass Index). National, regional, and global trends in adult overweight and obesity prevalences. Popul Health Metr. 2012: 10(22):1-16.

3. Ministério da Saúde (BR). Secretaria de Vigilância em Saúde. Secretaria de Gestão Estratégica e Participativa. Vigitel Brasil 2014: vigilância de fatores de risco e proteção para doenças crônicas por inquérito telefônico. Brasília: Ministério da Saúde; 2015.
4. Ministério da Saúde (BR). Secretaria de Atenção à Saúde. Departamento de Atenção Básica. Estratégias para o cuidado da pessoa com doença crônica: obesidade. Brasília: Ministério da Saúde; 2014.

5. Macedo TT, Palmeira CS, Guimarães AC, Lima ML, Ladeia AM. The meaning of obesity: the perception of obese patients. Rev Enferm UFPE online [Internet]. 2013 [cited 2016 Jul. 8]; 7(esp):706473. Available from: http://www.revista.ufpe.br/ revistaenfermagem/index.php/revista/article/ viewArticle/4714

6. Fontanella BJ, Luchesi BM, Saidel MG, Ricas J, Turato ER, Melo DG. Sampling in qualitative research: a proposal for procedures to detect theoretical saturation. Cad Saúde Pública. 2011; 27(2):389-94.

7. Minayo MC. O desafio do conhecimento: pesquisa qualitativa em saúde. São Paulo: Hucitec; 2014.

8. Ríos-Martínez BP, Rangel-Rodríguez GA. Selfperception in obese patients. Rev Med Inst Mex Seguro Soc. 2011; 49(1):23-8.

9. Pinto M, Bosi ML. Muito mais do que pe(n)sam: percepções e experiências acerca da obesidade entre usuárias da rede pública de saúde de um município do Nordeste do Brasil. Rev Saúde Coletiva. 2010; 20(2):443-57.

10. Vagetti GC, Barbosa-Filho VC, Boneti-Moreira N, Oliveira V, Schiavini L, Mazzardo O, et al. Older women associating obesity with a negative perception of their health: a study in low-income neighborhoods in Curitiba, southern Brazil. Rev Salud Publica. 2012; 14(6):923-36.

11. Schultheisz TS, Aprile MR. Autoestima, conceitos correlatos e avaliação. Rev Equil Corp Saúde. [Internet]. 2013 [citado 2016 Jul. 8]; 5(1):36-48. Disponível em: http://www.pgsskroton.com.br/ seer/index.php

12. Silva GA, Lange ES. Imagem corporal: a percepção do conceito em indivíduos obesos do sexo feminino. Psicol Argum online [Internet]. 2010 [citado 2016 Jul. 8]; 28(60):43-54. Disponível em:http://www2.pucpr.br/reol/index.php/ PA?dd1=3509\&dd99=view 
13. Sutin AR, Terracciano A. Perceived weight discrimination and obesity. Plos One. [Internet]. 2013 [cited 2016 Jul. 8]; 8(7):2485-8. Available from:http://www.ncbi.nlm.nih.gov/pmc/ articles/PMC3722198/

14. Bueno JM, Leal FS, Saquy LP, Santos CB, Ribeiro RP. Educação alimentar na obesidade: adesão e resultados antropométricos. Rev Nutr. 2011; 24(4):575-84.

15. Soares CS, Santos I, Berardinelli LM. Obesity as a social problem: identifying guidance needs of nursing for self-care. Rev Enferm UFPE online [Internet]. 2010 [cited 2016 Jul. 8]; 4(1):18-27. Available from: http://www.revista.ufpe.br/ revistaenfermagem/index.php/revista/article/ viewFile/520/pdf_264

16. Santos A, Pasquali R, Marcon S. Feelings and experiences of obese participants in a support group: an exploratory study. Online Braz J Nurs. [Internet]. 2012 [cited 2016 Jul. 8]; 11(1):3-10. Available from: http://www.objnursing.uff.br/ index.php/nursing/article/view/3251/html
17. Schencman P. O gerente está doente. Uma perspectiva sociológica sobre os vínculos existentes entre obesidade e trabalho. Rev Saúde Coletiva. 2013; 23(2):613-28.

18. D’Alencar ER, Lima MM, Mendonça PM, Custódio IL, D’Alencar BP, Lima FE. Ações de educação em saúde no controle do sobrepeso/obesidade no ambiente de trabalho. Rev Rene. 2010; 11(1):17280.

19. Egan AM, Mahmood WA, Fenton R, Redziniak N, Kyaw Tun T, Sreenan S, et al. Barriers to exercise in obese patients with type 2 diabetes. Q J Med. 2013; 106(7):635-8.

20. Silva SS, Maia AC. Patients' perceptions, health and psychological changes with obesity treatment: Success and failure in a triangulation study. Open Access. 2013; 5(11):1750-9. 